\title{
THE IMPACT OF SOCIAL MEDIA AND SMARTPHONE USE ON THE RELATION BETWEEN THE USERS AND THE NEWS IN TURKEY
}

\author{
Ceren BİLGICI \\ İstanbul Kültür University, Turkey \\ cerenbilgici@gmail.com
}

\begin{abstract}
In this article, the experiences of the users with regard to the development of new technologies (of telecommunication, internet and cellphones) in Turkey on the internet are analyzed. The objective is to demonstrate the effects of the new technologies on the practices of the internet users reaching the news via cellphone. The purpose is to observe the transformation of the daily practices on the Internet due to the evolution of the broadband, the development of the telecommunication market, the development of the adapted interface to the website ergonomics and the invention of the new technological devices such as smartphones. The aim of this study is to find out the new ways of searching news via mobile phones. We analyzed the relation between Turkish users and new information and communication technologies and the transformation of the habits of searching news and the role of social media platforms in this subject. According to our studies, the digitalization of the news, evolution of smartphones and the development of social media affect the habits and manners of reading, searching and sharing news. Nowadays, the practices of online news consumption are multiple. The interface ergonomics of websites and applications has a significant role on the media preferences of the users.
\end{abstract}

Keywords: Social Media, Internet, Smartphone, Online Journalism, Interface Ergonomics

\section{TÜRKIYE'DEKİ SOSYAL MEDYA VE AKILLI TELEFON KULLANIMININ KULLANICI-HABER İLISSKISİNE ETKİSI}

ÖZ

$\mathrm{Bu}$ makalede, Türkiye'de kullanımı giderek artan akıllı telefonların ve telekomünikasyon teknolojilerinin kullanıcıların mobil internet deneyimleri üzerindeki etkileri incelenecektir. Amaç, yeni iletişim teknolojilerinin, akıllı telefonlarla habere ulaşan kullanıcıların kullanım alışkanlıkları üzerindeki etkisini açıklamaktır. $\mathrm{Bu}$ araştırmanın hedefi; akıllı telefonların gelişiminin, Web ergonomisine uygun olarak tasarlanan arayüzlerin ve telekom sektöründeki gelişmelerin, kullanıcıların mobil internet üzerinde gerçekleştirdikleri davranışları ne yönde etkilediğini tespit edebilmektir. Bu bağlamda, akıllı telefonlarından habere ulaşan kullanıcıların, haber arama, okuma, paylaşma konusunda kendine yarattığı yeni yolları keşfetmeye çalışacağız. Böylece, bu çalışmayla, Türkiye'deki kullanıcıların yeni iletişim teknolojileriyle ilişkisini ve yükselmekte olan sosyal medya platformlarının haber aramadaki rolünü analiz edeceğiz. Araştırmamızın sonuçları; sosyal medya platformları ve akıllı telefonların gelişiminin ve haberlerin dijitalleşmesinin haber okuma, arama ve paylaşma alışkanlıkları üzerinde önemli bir dönüştürücü etkisi olduğunu göstermektedir. Günümüzde, internet üzerindeki haber tüketim şekilleri oldukça fazladır. Akıllı telefon uygulamalarının ve internet sitelerinin arayüz ergonomisine uygun tasarımlarının kullanıcıların medya tercihleri üzerinde büyük rolü vardır.

Anahtar Kelimeler: Sosyal Medya, Internet, Akilli Telefon, Internet Gazeteciliği, Arayüz Ergonomisi 


\section{INTRODUCTION}

In the mid-1990's, the users firstly began being amazed by the vast amount of available information to access easily by using the first search engines and the opportunity of a communication by e-mail. In time, they have begun making online purchases, instant messaging and then finally 'participating' due to the 'Web 2.0' in the late 2004: blogs and social networks have been finally here. Internet users who merely browsed, searched, surfed, have begun sharing, acting and participating. Thus, the Web has became a platform more open to users and users have became actors that are shaping the Web, the websites, the content. Nowadays, this alteration in the practice is at the heart of the evolution of information and communication technologies.

Over the last two decades of the 20th century, developments in telecommunications, technology and the internet turn upside down the economy, the world affairs, the administration and all the social life and even the everyday life. The Internet and the mobile digital players became the most powerful actors of growth and productivity. The digital age has created "homo internauticus", the current human being who is more active than passive. ${ }^{1}$

For the printed media, the digital development resulted in an alteration in the functioning of the sector and as well as the journalistic treatment in the manners and habits of searching for news. Thus, new technologies have turn upside down the pyramid of the values of the sector and its functioning. Changes are taking place in newsrooms as a result of the shift towards multimedia, multiplatform news consumption. The newspapers are transformed into multimedia news factories. ${ }^{2}$ "Technology has enriched the content, or rather the content suits the facilities that are provided and produced by technology." ${ }^{3}$ Nowadays, social and mobile technologies reshape the landscape of the news.

Today, research, production and dissemination of news change deeply. The digital revolution generates a perspective of industrial and commercial development in the media sector. Thus, the manners of reading news and the habits of media consumption change. Any revolution in the media needs an adaptation of the society at the same time. Furthermore, in order to achieve this transformation, firstly we must analyze and understand the habits of reading practices and the reactions of society in front of the new media. This article aims to analyze the effects of new media and smartphones on searching, reading and sharing the news.

\section{METHODOLOGY}

Over the past years, the place and the role of users have become more important in the field of information and communication technologies. New technologies shape the usage. The observation of technological devices usage, i.e. what people do actually with these technological devices, can develop a relevant methodological input to capture the action of the technique in the society. ${ }^{4}$ For this analysis, we apply several different methods. We try to understand 'new' user by using two quantitative surveys conducted in 2010 and then in 2014 with the same 62 Turkish users and interviews between these years with 30 users selected from among the participants of the surveys. Though our sample is small for a quantitative survey, we believe this analysis yields valuable insight into the news habits of young Turkish mobile Internet users and think this research provide useful information to understand the 'new' user. We tolerate our small sample size of the quantitative survey with our in-depth interviews. Our structured interviews take place through an open end and closed end questionnaire.

The subject of this research is the evolution of the relation between the news and the smartphone users in Turkey: the traditional media vis-à-vis social media. We analyze the practices of the Internet

\footnotetext{
${ }^{1}$ PALMER Michael, L'Homo Informans - L'urgence des news au fil des millénaires, Editions L'Amandier, Paris, 2011, p.439

${ }^{2}$ AGNES Yves, Manuel de Journalisme, La Découverte, Paris, 2002, p. 120

${ }^{3}$ WOLTON Dominique, Informer n'est pas communiquer, CNRS Editions, Paris, p.81

${ }^{4}$ BRETON Philippe, PROULX Serge, L'explosion de la communication, Editions Découverte, Paris, 2006, p.254
} 
users facing the development of new information and communication technologies in Turkey. Our objective is to identify the factors affecting mobile news consumption habits.

In this regard, we ask these main questions that direct us to the hypothesis of this article:

- How do the new technologies in the field of telecommunications, the Internet and the smartphone influence the practices of users?

- How do today's users share and search the news via smartphones?

- What is the role of social media in everyday life to the research and production of news against the traditional media?

-What are the effects of the interface ergonomics on searching the news in everyday life?

Our first hypothesis is that the evolution of smartphones that are currently at the center of everyday life of young users who initially were only using the Internet on their computer, transforms the habits of searching for online news. Smartphone users have other habits of searching and reading the news on the smartphones than on the computers. The device used for searching and reading the news has an effect on the practices to get news.

Our second hypothesis is that social media is currently an important source of the news for new users when comparing with traditional media. Today, social media is an open platform for sharing and exchanging news for the smartphone users. Due to the well adaptation of the interfaces of social media applications to Web ergonomics, it makes the access to the news much easier than the news applications/websites.

\section{DISCUSSION}

\section{The use of the Internet on the cellphone in Turkey}

The consumption of online news practices increase due to the new telecommunications technologies and the offers of the mobile operators making technology more accessible to individuals.

In this part, we will analyze the results of the survey conducted in 2010 about the usage of the mobile Internet users in Turkey.

The survey conducted in 2010 and 2014 contains 41 questions. These questions focus on five main topics: the relation between the users and the cellphones, the practices of the users on mobile Internet, the use of social media on mobile Internet, the search for news on social media on smartphones and the search for information on the news websites.

The use of new technologies and new media is widespread among young people in Turkey. Thus, the sample of users include young people who practice the new digital media in their everyday lives on their computers as well as on their cellphones. Hence, we will try to see the new possibilities of searching for news on the Internet.

The selected sample consists of 62 Turkish users who are inhabitants in Turkey. The ages of these users are between 18-34 in 2010. This choice focused on this segment of the population that owns smartphones mostly. These users are the most active users of the mobile Internet. They are curious to learn new technologies and wish to use them in their everyday lives. Also, they are interested in the news.

$66 \%$ of these users are between 26-30 years old, $26 \%$ are between $18-25$ years old and $8 \%$ are between 31-34 years. $57 \%$ of these users are holders of a master's degree, $33 \%$ have a Bachelor's degree and $10 \%$ are still students. Their town of residence: $92 \%$ live in Istanbul (the largest city of Turkey, where $20 \%$ of the country's population reside), 3\% in Ankara (the capital and the second largest city of the country in terms of population), $3 \%$ in Izmir (the third city of the country in terms of population) and $2 \%$ in Adana (the fourth city in the country in terms of population). 
We will see firstly the relation of our sample with cellphones and then analyze the practices of the Internet on the cellphone. Then, we will discover the main reasons for the use of social media on the smartphone. After achieving this information, we will try to understand the practices of searching for news on social media and searching for news on the news websites on the cellphone.

\section{The relation between the users and the cellphones}

It is essential to know the level of competence for the use of the cellphone and the relation between the sample and the new technologies of telecommunications for our analysis. $52 \%$ of the sample uses the cellphone in everyday life for $10-11$ years, $28 \%$ for $12-13$ years, $16 \%$ for less than 10 years, and only $3 \%$ use it for $14-15$ years.

The development of the mobile Internet is accepted as a convergence and provides user comfort and improved ergonomics. We are facing a big change in the consumption of mobile content, due to the smartphones in Turkey, as well as in the world. During 2007 summer, after the launch of the iPhone from Apple in the United States, Google and Yahoo have experienced 'dramatic increase' traffic on their directly accessible websites from the screen of the iPhone. ${ }^{5}$ With the explosive growth of the mobile Internet, smartphones are used now several hours of the day by individuals and are used also as a computer rather than a telephone.

We clearly see the rise of smartphones from the sample users who all connect on mobile Internet. 24 users among the 62 have an Apple iPhone which is the first device allowing an effective use of the Internet on the cellphones; 18 respondents prefer Nokia; 12 respondents use a model of Blackberry and other 4 have a cellphone from the HTC brand; 3 respondents have a cellphone from the Samsung brand and only 1 user prefer the LG brand. $73 \%$ of the sample has a single cellphone. On the other hand, $27 \%$ use two cellphones in daily life. As favorite mobile operators, 47 of the 62 users have a subscription with Turkcell, 8 with Vodafone and 7 with Avea. 46 people use a postpaid package while 16 people prefer prepaid card.

The six essential services (in order of importance) mobile phones according to the sample are: the voice call, Internet, SMS, applications, GPS and MMS. 60 users of the 62 find the voice call indispensable, 57 users say that the Internet is an indispensable service of cellphone, 55 users voted for SMS, 27 users for the applications, 21 users for GPS and 10 users for MMS. This shows us that for $92 \%$ of the users mobile Internet is essential. Thus, we find that mobile Internet is now a necessity.

\section{The use of the mobile Internet}

The arrival of 3 rd generation mobile $(3 \mathrm{G})$, both multimedia and broadband won a great success. The arrival of the 3rd generation of mobile (3G) took its place in July 2009 in Turkey. The response of our sample to the question "for how many years have you connected on the Internet on the cellphone?" shows the growth of the mobile Internet after the arrival of the 3rd generation on the Turkish market, because more than half of the sample began to use it for less than a year. $31 \%$ of the sample uses mobile Internet for less than 6 months, $23 \%$ for less than a year, $15 \%$ less than 2 years, $15 \%$ for $2-3$ years, $15 \%$ for $4-7$ years and $1 \%$ for 10 years.

The smartphone is now at the center of the digital life of the users. According to them, the most important thing is to enjoy content, wherever they are. The main reason for the use of the Internet on the cellphone is the use of e-mail. Ranked second are the social media, the third one is looking for news and the fourth one is the chat.

The most important news field according to the respondents on the cellphone is the breaking news. 30 users say that the breaking news is their priority in searching for information on the cellphone. For 12

${ }^{5}$ LOMBARD Didier, Le village Numérique Mondial, Odile Jacob, Paris, 2008, p.172 
respondents, the most important area is the sport, 6 say that it is the traffic, 5 think that it is the weather, for 3 respondents it is the international news and also for 1 the economy is the most important.

\section{The practices of the social media on the smartphone}

Due to $64 \%$ of users, the most used social media is Facebook. Twitter is second with $34 \%$. The main reason for the usage of social media on the cellphone is communication with friends for 20 users. According to 15 users, the social media sites are essential to follow the breaking news on the smartphone and for 9 users to read comments about the news. 9 users prefer social media primarily for fun. The issues shared on the social media more on the cellphone are "the comments on the news" for 21 users, "sentimental info / reactions" for 17 users, "information about what they're doing" for 8 users, "comments on sport" for 2 users, "information on their studies / their profession" for 1 user. 4 users say that they write nothing ever on social media on the smartphone. $60 \%$ of users share more often comments on social media on the cellphone. $15 \%$ often share information/news, $13 \%$ share photos. For $8 \%$ music is the most shared, while for $5 \%$ it is video.

\section{News on social media}

The users adapt the searching of news during a daily cellphone use with the arrival of $3 \mathrm{G}$ and the rise of smartphones that make access to the Internet much easier. Smartphone creates new opportunities for accessing to the news on the new websites, such as social media that makes reaching news much quickly. The answer to the question "Do you connect on social media to get news?" is positive for $63 \%$ of the users. $37 \%$ of respondents do not use social media for searching news on the cellphone. $52 \%$ of users use social media to learn the breaking news, $19 \%$ use for the news in the field of sport and $8 \%$ use for news on culture and art. The answer to the question "Do you connect to social media on your cellphone to read the comments about the news or events?" is positive for $53 \%$ of users and negative for $47 \%$ of users. According to $63 \%$ of the users, the social media is a source of the news on the Internet when using the smartphone, while $29 \%$ of them do not find it useful. $8 \%$ has "no opinion" on this subject.

\section{News on smartphones}

Technological advances significantly change the habits of getting news and represent new opportunities to compete with traditional media. On the other hand, it must be noted that traditional media also find their place in this new media world. Readers, who are moving away the printed press, do not leave completely 'their' newspapers, however interested in new more practical ways of access to the news produced by traditional media. 'Traditional' readers become cellphone users that expect traditional media should be adapt to the new needs of the readers. Among the 62 users, 44 of them visit news websites on the cellphone. On the other hand, 18 users prefer not to visit them on the cellphone. $57 \%$ prefer to visit $2-3$ news websites per day while $36 \%$ visit only a single news website per day. In the websites most favorite on the cellphone, the forefront is 'ntvmsnbc.com' cited by 29 users. The second rank is 'hurriyet.com.tr' according to 20 users, the third one is 'milliyet.com.tr' for 11 users. The fourth rank is 'radikal.com.tr' for 7 users, and the fifth rank is 'haberturk.com' for 6 users. The sixth rank is 'cumhuriyet.com.tr' cited by 5 users.

$75 \%$ of the sample says that they "never" leave comment on news on websites via cellphone. $16 \%$ of the sample make comments "rarely", 7\% "sometimes" and 2\% "most of the time".

\section{The transformation of news consumption habits}

"At the methodological level, researchers have faced a slippery ground due to the explosion of news on various media supply and the very rapid commoditization of digital practices. ${ }^{\prime \prime}$ While new media is a very changeable area of research, therefore it is difficult to analyze for researchers. In this perspective, surveys and interviews that we have conduct on several occasions between the years

\footnotetext{
${ }^{6}$ JOUËT Josiane, RIEFFEL Rémy (dir.), S'informer à l'ère numérique, Presses Universitaires de Rennes, Rennes, 2013, p.193
} 
2010-2014, were used to observe the quick change of the users habits, the arising new news formats and ownership by users of new devices developed as 'smartphones'. In this chapter, we will analyze the transformation on the new practices of Turkish users for searching and sharing news, the alteration of the choice of websites in time (with the rise of social media) and the reasons for wanting to make their choice of media to get news.

Analyzing new practices of users changing more closely is significant. In this chapter, the results of the survey that we conducted in 2014 about the use of the mobile Internet users in Turkey will be analyzed. $60 \%$ of respondents have an Apple's iPhone; $25 \%$ prefer Samsung; $4 \%$ of respondents use a Blackberry model and 3\% have a cellphone of the Nokia, 3\% have a HTC, $3 \%$ use LG; only $2 \%$ of the sample prefer the Asus brand. The choice of the brand of the smartphones prove us a rise of use of Apple's iPhone and smartphones of the Samsung brand due to the comparison the rate of usage between 2010-2014. In 2010, only 39\% of respondents use an iPhone. Furthermore, only 5\% of users had a Samsung brand cellphone. The brands Nokia and Blackberry have lost their popularity among these users. According to the frequency of use, $97 \%$ of the sample uses the Internet on the cellphone every day while $3 \%$ use it daily, except on weekends. The rate of use of mobile Internet every day in 2010 was only $84 \%$. It is important to note that in our sample, the use of mobile Internet becomes as usual as voice calling or sending SMS. According to our data, $48 \%$ of the users connect more than 20 times a day (31\% in 2010) and $45 \%$ of the users connect mobile Internet $10-20$ times a day $(25 \%$ in $2010), 7 \%$ of the users are only using 5 to 6 times a day (37\% in 2010).

Thus, the smartphone and the use of the Internet on smartphone are at the center of the digital life of the users. This transformation on the frequency of use of the mobile Internet is affected by the improvement of the interface design over time, mobile Internet connections and the customer package offers of mobile operators including the Internet more affordable for users. Six essential services (in order of importance) of the smartphone according to our sample are: the Internet, voice call, applications, GPS, SMS, video call. This study shows that the Internet became the most important service on cellphones for 62 users of our sample while in 2010 it was ranked second after the voice call.

Table 1 : List of the most important activities on the cellphone

(Comparison prepared according to our survey data between the two surveys carried out in 2010 and in 2014)

(Table prepared according to the survey data)

\begin{tabular}{|l|l|}
\hline $\mathbf{2 0 1 0}$ & $\mathbf{2 0 1 4}$ \\
\hline $1^{\mathrm{e}}$ Voice call & Internet \\
\hline $2^{\mathrm{e}}$ Internet & Voice call \\
\hline $3^{\mathrm{e}} \mathrm{SMS}$ & Applications \\
\hline $4^{\mathrm{e}}$ Applications & GPS \\
\hline $5^{\mathrm{e}} \mathrm{GPS}$ & SMS \\
\hline $6^{\mathrm{e}} \mathrm{MMS}$ & Video call \\
\hline
\end{tabular}

The three main cellphone activities carried out on the Internet are the e-mail with a rate of $67 \%$, searching on their center of interest with a rate of $51 \%$ and social media with a rate of $53 \%$. Fourth is the chat with a rate of $42 \%$ and searching for the news is in the fifth place with a rate of $37 \%$. As we can see in the table below, searching for information has lost its importance for most of those surveyed while the e-mail, social media and the chat retain their importance for the sample. 


\section{Table 2 : List of main activities on the mobile Internet (Comparison between the two surveys carried out in 2010 and in 2014) (Table prepared according to the survey data)}

\begin{tabular}{|l|l|}
\hline $\mathbf{2 0 1 0}$ & $\mathbf{2 0 1 4}$ \\
\hline $1^{\mathrm{e}}$ E-mail & E-mail \\
\hline $2^{\mathrm{e}}$ Searching news & Research about the central personal interests \\
\hline $3^{\mathrm{e}}$ Social media & Social media \\
\hline $4^{\mathrm{e}}$ Chat & Chat \\
\hline
\end{tabular}

$60 \%$ of users accept Google as the most convenient way to access news they are looking for on the smartphones while only for $23 \%$ it is social media. News websites come fourth with a rate of $4 \%$, after the Wikipedia with a rate of $11 \%$. The results of the interviews we have done with a part of the sample of the survey, the interface design of news websites and applications are not suitable for news searching on a particular interest. On the other hand, social media is more practical, because they have the opportunity to find all the news very quickly on their timeline, among the accounts that they follow, however it still isn't a more convenient way than Google. 94\% of the users report connecting on social media in smartphones to get news. Only $6 \%$ do not connect on social media especially to get news. Attributed to the 'yes' response rate was $63 \%$ in 2010.

$91 \%$ of users who responded to our survey reported checking news websites on the cellphone. Only $9 \%$ of users do not prefer news websites. In 2010 , the use of these websites was $71 \%$. $39 \%$ of the sample visits 2-3 news websites per day and 37\% of them prefer to visit more than 3 websites. On the other hand, $77 \%$ never leave comments on news websites when using the cellphone. 23\% make comments 'rarely'. We see no increase of the population who prefer to leave comments since 2010 ( $25 \%$ was the rate of users who leave comments 'rarely', 'sometimes', 'most of the time'.)

\section{The main source to get news}

According to $55 \%$ of participants, the main source for news in their daily lives is Internet while due to $40 \%$ it is the mobile Internet. It is only $3 \%$ of the sample saying that television remains the main source of information and for $2 \%$ it is still newspapers in print copy. The survey shows the rise of mobile Internet, because the mobile Internet rate was $19 \%$ in 2010 . In four years, the habits to get news experience a transformation due to the mobile Internet and the perception towards the mobile Internet is also changed for a significant portion of our sample.

\section{The role of interface ergonomics on searching news}

The smartphone is now at the center of the digital life of users. According to the users, the most important thing is to enjoy content, wherever they are. While mobile phones create an opportunity to stay connected continuously, they also have at the same time some usage problems. These problems are related to the small screen size, the connection problems and the problems concerning the protection of privacy and security for the most of the time. ${ }^{7}$ The user experience for mobile platforms

\footnotetext{
${ }^{7}$ Kaikkonen, A.: Internet on Mobiles: Evolution of Usability and User Experience. Doctoral Dissertation, Helsinki University of Technology, Faculty of Information and Natural Sciences Department of Computer Science and Engineering, 2009, p. 48
} 
is one of the most important issues in the topics of human-computer interaction, because the cellphone users continue to have problems about usability of the mobile application interfaces and mobile devices. Due to the ergonomics of the devices and used interfaces, website have power for creating new ways for transformation of even a very normal and natural activity, such as reading. The digitization of news influences the habits of reading and creates a new vision to the concept of reading. Reading manners that grow in digital environments differ from those on paper. Hypertext links and the multiplication of the elements on the pages transform reading into zapping. ${ }^{8}$ Also, after the interviews that we have done between the years 2010-2014, we find that the social media applications are more attractive to access news due to their interface design and their homepage that has a form of newsfeed that makes access to news easier and more convenient. All of the 30 users asked about their choice declare that access to social media applications is more practical and faster than accessing to news websites applications.

User $1^{9}$ explains: "When I try to access on applications, I see difficulties in downloading and it takes a lot of time. But if I connect on Twitter, it's more convenient. In addition to that, I see at once the accounts of the newspapers, journalists and my friends. So, I'm learning all things that interests me."

User 2: "The problem with applications of newspapers is that there are a lot of things and I have to read many things that do not interest me to get the news that interests me. It is a waste of time. On the other hand, on the social media, I personally select all people to reach all the news."

User 5 explains his first choice, Twitter by saying: "According to me, the most significant application on the cellphone is Twitter. It allows me to directly access the breaking news, sport news and also information about my friends."

The user 6 uses Twitter instead of television: "I can't stand to watch the news on TV, I use Twitter instead of it."

User 15 explains: "I firstly consult Twitter to learn the news of the day, I have a lot of people in my list, when something important happens, I can learn easily."

User 9 explains his preference for Google: "I prefer Google seeking news on a specific topic because when I'm on a news website, sometimes I lose myself." For User 27, Google is better than the news websites for searching: "It is better because it offers me a diversity of news."

The time spent during searching and connecting the application is very important for users when making the choice of applications. Although the content is also very important, on the list practice comes first.

\section{CONCLUSION}

Through the research, we conducted an analysis on the effect of new media and the different tools on the habits of searching and sharing news of the users in Turkey. We find out how the evolution of the technologies of mobile devices and the news, media offers (the multiplicity of websites - news websites and social network, the evolution of news services, development of design) transform the habits of online users to get news.

Due to the research, it is clear that the digitization of the news influences the manners and habits of reading and creates a new vision to the concept of reading. The consumption of online news increases today due to the new information and communication technologies. An adaptation of the daily uses of smartphones is provided among users. Social media sites have been considered and used as a source

\footnotetext{
${ }^{8}$ BIAGINI Cédric, L'emprise numérique Comment Internet et les nouvelles Technologies ont colonisé nos vies, Editions L'échappée, Montreuil, 2012, p.105

${ }^{9}$ We give numbers to the 30 participants of our interviews, thus we can respect their confidentiality.
} 
of information according to the practices of users especially since 2013. It is clear that the ergonomics of the interface design plays a key role in their choice. Although they also continue to get news from the traditional media, especially on newspaper websites, their interest in these sites is reduced on the smartphone.

Information and communication technologies shape what we see and how we see it. The reading skills, reflection are redesigned by new technologies. Information is increasingly reformatted by social media and smartphones. According to the research, Twitter and Facebook compete with the traditional media to be the essential tools for accessing the news particularly on mobile.

The habits of access to news have evolved with the rise of the mobile Internet. The development of mobile Internet enabled us to see new perspectives of usage for interpersonal communication as well as for searching and sharing news.

Smartphones that allows new users to be always connected, has become an indispensable tool of everyday life. Today the mobile Internet is considered the essential activity of a cellphone by our sample. Of course, "when a technique is used more, people learn to use it better, and when they optimizes its use more, it becomes more powerful." ${ }^{\prime 10}$ Social media is considered and used as a source of information according to the practices of users and it is clear that the ergonomics of the interface design plays a key role in their choice. Although they continue to track news from traditional media, especially on newspaper websites, their interest in these websites is reduced considerably. This is based on the difficulty of the surf in a news website in a limited time on the mobile phones, because of the less practical design of news applications than the social media applications. In addition to that, the encountered news excess in the application of news websites is a second obstacle for the users. The time spent to get news, especially on mobile is the priority of the users. They intend to learn the maximum amount of news belonging to their center of interest in a minimum time.

\section{REFERENCES}

AGNES Yves, Manuel de Journalisme, La Découverte, Paris, 2002

BIAGINI Cédric, L'emprise numérique Comment Internet et les nouvelles Technologies ont colonisé nos vies, Editions L'échappée, Montreuil, 2012

BRETON Philippe, PROULX Serge, L'explosion de la communication, Editions Découverte, Paris, 2006

FLICHY Patrice, L'innovation technique, Editions La Découverte, Paris, 1995

JOUËT Josiane, RIEFFEL Rémy (dir.), S'informer à l'ère numérique, Presses Universitaires de Rennes, Rennes, 2013

KAIKKONEN A.: Internet on Mobiles: Evolution of Usability and User Experience. Doctoral Dissertation, Helsinki University of Technology, Faculty of Information and Natural Sciences Department of Computer Science and Engineering, 2009

LOMBARD Didier, Le village Numérique Mondial, Odile Jacob, Paris, 2008

PALMER Michael, L'Homo Informans - L'urgence des news au fil des millénaires, Editions L'Amandier, Paris, 2011

WOLTON Dominique, Informer n'est pas communiquer, CNRS Editions, Paris

10 FLICHY Patrice, L'innovation technique, Editions La Découverte, Paris, 1995, p.153 